\title{
Neighborhood Sustainability Assessment Tools and a Comparative Analysis of Five Different Assessment Tools
}

\author{
Mahalle Sürdürülebilirlik Değerlendirme Araçları ve Beş Farklı \\ Değerlendirme Aracına Illişkin Karşılaştırmalı Bir Analiz
}

\author{
Serkan Yıldız, ${ }^{1}$ Mustafa Yılmaz, ${ }^{1}$ Serkan Kıvrak, ${ }^{2}$ Arzuhan Burcu Gültekin ${ }^{3}$ \\ 1'Department of Civil Engineering, Turkish Military Academy, Ankara, Turkey \\ ${ }^{2}$ Department of Civil Engineering, Anadolu University, Eskişehir, Turkey \\ ${ }^{3}$ Department of Real Estate Development And Management, Ankara University, Ankara, Turkey
}

\begin{abstract}
The search for finding solutions for urban problems led to the emergence of efforts to apply the concept of sustainability to cities and hundreds of assessment tools have been developed to assess the sustainability from buildings to neighborhoods and urban scales. Neighborhood Sustainability Assessment (NSA) tools, which examine the buildings together with their environments and evaluate the topics like society, land usage, transportation, water, air, energy and biologic diversity as a whole economically, environmentally and socially, are the tools that have been presented in recent years and started to be recognized and used very recently. In this study, it was aimed to introduce relatively mostly known 5 NSA tools, reveal the differences and similarities among them through various comparisons and make an assessment. The main point of the study was comprised of determining the approach differences between the systems in respect of the main goals of sustainability through the comparison of each system's main category and criteria in terms of scope, number and scoring. With this study, the world literature that is quite limited on this topic will be developed and contribution will be made to increase the awareness of the topic. It is also aimed to contribute establishing an assessment tool in Turkey.
\end{abstract}

Keywords: Assesment tool; neighborhood; sustainability; urbanization.

\section{ÖZ}

Dünya, her geçen gün ağırlaşan kentsel sorunların çözümünü sürdürülebilirlik kavramının kentlere uygulanmasında bulmuş, bu kapsamda son yıllarda binalardan, mahalle ve kente uzanan ölçekte çok sayıda sürdürülebilirlik değerlendirme sistemi geliştirilmiştir. Binaları çevreleri ile birlikte değerlendiren ve toplum, arazi kullanımı, ulaşım, su, hava, enerji ve biyolojik çeşitlilik gibi konuları ekonomik, çevresel ve sosyal açıdan bir bütün olarak ele alan Mahalle Sürdürülebilirlik Değerlendirme (MSD) araçları son yıllarda geliştirilen ve yeni yeni kullanımına başlanan araçlardır. Bu çalışmada göreceli olarak daha çok bilinen 5 MSD aracının tanıtılması, çeşitli karşılaştırmalar yapmak suretiyle aralarındaki benzerlik ve farklılıkların ortaya konması amaçlanmıştır. Çalışmanın ana temasını her bir aracın ana kategorileri ve kriterlerini amaç, sayı ve puanlama açısından karşılaştırarak sürdürülebilirliğin hedefleri açısından araçlar arasındaki yaklaşım farklılıklarını belirlemek oluşturmuştur. Çalışma ile konu hakkındaki kısıtlı literatürün zenginleştirilmesine ve konuya ilişkin farkındalığın artırılmasına, ayrıca ülkemize özgü bir mahalle değerlendirme sistemi geliştirilmesi konusunda yürütülecek faaliyetlere ışık tutulmasına çalışılmıştır.

Anahtar sözcükler: Değerlendirme aracı; mahalle; sürdürülebilirlik; kentleşme.

Received: 15.05.2016 Accepted: 14.06.2016

Correspondence: Serkan Yildız. 


\section{Introduction}

A great part of the world population live in urban areas where main economic, social and environmental processes that affect the human communities come true and urbanization is today considered as one of the social processes which have a great effect on the environment at the local, regional and global scales (Turner vd., 1990). Besides the population increase, transition of employment from agriculture to industry causes a rapid increase in the urban populations especially in developing countries. London, which adopted the first title of city with a population exceeding one million in the $19^{\text {th }}$ century since the ancient Rome, carries the same title with 4I4 cities, most of which are in China, and it is assumed that this number will exceed 1000 within the next 35 years (Roosa, 2010). Cities, which expand at a speed beyond the available city planning and management capacities, cause lots of urban problems. The search for finding solutions for urban problems led to the emergence of efforts to apply the concept of sustainability, which had been presented in Brundtland Report in 1987 for the first time, to cities.

Sustainable city is the city where socioeconomic benefits are made compliant to concerns related to the environment and energy for the purpose of enabling the change within continuity (Geenhuisan ve Nijkamp, 1994). Today, all the concepts from reliable water resources to appropriate accommodation conditions, from employment to life quality and participation are evaluated as basic rights within the sustainable urbanization (Drakasis-Smith, 1997). Nowadays, hundreds of assessment tools have been developed to assess the sustainability from buildings to neighborhoods and urban scales. Assessment tools, which are based on the certification of the buildings known as environment -friendly or green, are recognized worldwide and used widely. On the other hand, neighborhood sustainability assessment (NSA) tools, which examine the buildings together with their environments and evaluate the topics like society, land usage, transportation, water, air, energy and biologic diversity as a whole economically, environmentally and socially, are the tools that have been presented in recent years and started to be recognized and used very recently. In this study, 5 NSA tools are introduced and the differences and similarities among them are revealed.

\section{Urban Sustainability Assessment Tools}

Assessment can be made in relation to cities as single buildings, neighborhood and city at three levels with the assessment tools. At the beginning, assessment tools focused on the environmental performances of the single buildings (Sharifi, 2015). Firstly in 1990, the Building Research Establishment Environmental Assessment Method (BREEAM) system was developed to assess various environmental subjects rela- ted to buildings simultaneously and since then the number of the developed building, in other words, green building assessment systems has increased (Sharifi, 20I3). The aforementioned tools implement the multidecision approach and evaluate the building performances in terms of various criteria such as energy yield, water yield, carbon dioxide emission, internal air quality, accessibility, visual, auditory and thermal comfort (Soebarto ve Williamson, 200I; Mateus ve Bragança, 20II). Today, The Leadership in Energy and Environmental Design (LEED), BREEAM and Comprehensive Assesment System for Built Environment Efficiency (CASBEE) are known as the outstanding assessment tools of this type worldwide.

City assessment tools help the users to understand the real status of their own cities. Today, many city rankings are published by various institutions such as "Livability Ranking" of Economist Intelligence Unit, "Quality of Living Survey" of Mercer Human Resource Consulting and "Global Power City Index" of the Mori Memorial Foundation. Except for the city rankings, the best planned sustainability assessment instrument at the city level is CASBEE-City, which was firstly introduced by the Japan Sustainability Buildings Consortium (JSBC) in 201 I, and its 2012 version was published as the last one. (Sharifi, 20I3) CASBEE has developed an assessment system based on the concept of environmental efficiency, differently from a simple summation of the points or credits given in each performance area with its unique assessment method (Kawakubo vd., 20II).

It has started to be realized since the beginning of this century that building assessment systems aren't adequate alone for the solution of the problems of the urban societies in relation to sustainability. (Bond ve Morrison, 201 I; Haapio, 2012). Both this situation and the argument of Choguill supporting that "as long as its constituents aren't sustainable, the general sustainability of a city will be limited" (Choguill, 2008) led to the occurrence of neighborhood assessment tools, which is the topic of this research. Neighborhoods are the elements which constitute the architectural, cultural and economic systems of the cities and NSA tools are considered as the latest generation of the effect assessment tools (Sharifi ve Murayama, 2013). Assessment at the neighborhood scale means the assessment of not only the single buildings, but also the areas among them, provided services, people living there, other living beings and synergy and activities among the elements within this wide range (Cole, 2010).

Even though NSA plays a significant role during the decision-making process for sustainable development, there is still a limited understanding of the efficiency of the NSA tools and real world implementations. Theoretically, most of our knowledge about NSA tools results from the studies on the examination of the similarities and differences between them 
and their assessment methodology (Haapio, 2012; Sharifi ve Murayama, 2013; Sharifi ve Murayama, 20l4). It was enabled to develop the world literature on this issue through the examination of the latest versions of the NSA tools with this study. The main point of the study was comprised of determining the approach differences between the systems in respect of the main goals of sustainability through the comparison of each system's main category and criteria in terms of scope, number and scoring.

\section{Introduction of Five Assessment Tools}

Neighborhood assessment tools evaluate and assess the status of a neighborhood in its way to sustainability and its success of achieving the sustainability goals in terms of a range of criteria and issues. According to Sharif, NSA tools have two different types: Tools embedded in the plans at the neighborhood scale and tools derived from the third party building assessment systems (Sharifi ve Murayama, 2013). In this study, third party assessment systems are discussed. For the selection of these tools, criteria of relatively common usage and recognition, opportunity of accessing open source information and being from various regions of the world were taken as a basis. For this purpose, those assessment tools were considered: CASBEE-Urban Development (CASBEE-UD developed by Japan Green Buildings Council' (JaGBC)) from Japan, BREEAM Communities (BREEAM Com developed by Building Research Establishment ${ }^{2}$ (BRE)) from the UK, LEEDNeighborhood Development (LEED-ND developed by US Green Building Council ${ }^{3}$ (USGBC)), Deutsche Gesellschaft für Nachhaltiges Bauen-Neubau Stadtquartiere/ New Urban Development (DGNB-NSQ/NUD developed by DGNB ${ }^{4}$ (German Sustainable Buildings Council)) from Germany and finally Green Mark for Districts (developed by Building and Construction Authority ${ }^{5}$ (BCA)) from Singapore.

LEED grading system is a green building assessment system which is most known worldwide, especially in the North America and used widely by many countries (Panahi, 2014). The opinion of insufficiency in the assessment systems for single buildings in terms of holistic sustainability development helped USGBC, U.S Natural Resource Defense Council and the Congress for the New Urbanism come together to develop the LEED-ND assessment system (Stone ve Joseph, 20I2).
BREEAM is known as the first building certification program. It was developed in England in 1990 only for offices at the beginning. The latest assessment instrument of the BREEAM assessment family has been BREEAM Com. BREEAM Methodology was formed on the basis of the European Union norms as the independent and third party assessment and certification standard (TURKECO, 20I5).

As a country with insufficient renewable energy resources, Singapore aimed at $35 \%$ improvement in energy efficiency until 2030 according to the levels of 2005 by increasing the efficiency (BCA, 20I3). The assessment instrument Green Mark for Districts, which is a member of the Green Mark assessment family - presented in 2005 to achieve that goal - was introduced on October 29, 2009 by the building and construction institution of Singapore Building and Construction Authority.

CASBEE was formed with the Support of the Ministry of Environment, Infrastructure and Transportation together with Japan Sustainable Building Consortium and Institute for Building Environment and Energy Conservation in 2001 (Oktay ve Özdede, 2012). In 2006, CASBEE-UD was established as a third party voluntary tool to direct the sustainable neighborhood development in Japan. It is different from the other assessment tools because of the difference in the scoring system and nonexistence of international applicability (Orova ve Reith, 2013).

DGNB was established in 2007 in order to prompt the sustainable and economically efficiency buildings more strongly in the future. DGNB-NUD sustainability assessment system was published in 2012. DGNB-NUD system makes the neighborhood assessments over five titles as environmental quality, economic quality, sociocultural and functional quality, technical quality and process quality. These titles are divided into a range of subgroups consisting of various assessment parameters.

General information that belongs to the five assessment systems given above, implementation scales and discovered certificated project numbers are presented in Table I. Within the scope of the study, 2009 and 2012 versions of LEED and DGNB NSA tools, which are the first still valid versions, and the latest versions of BREEAM, CASBEE and Green Mark

\footnotetext{
USGBC founded in 1993, is a private, membership-based non-profit organization that promotes sustainability in buildings design, construction, and operation. USGBC was one of eight national councils that helped found the World Green Building Council (WorldGBC) in 1999.

2 BRE is a former UK government establishment (but now a private organization) that carries out research, consultancy and testing for the construction and built environment sectors in the United Kingdom.

3 DGNB was founded in 2007 by 16 initiators from various subject areas within the construction and real-estate sectors. The aim was to promote sustainable and economically efficient building even more strongly in future.

4 JaGBC is an organization working to promote international information exchange about green building and living. It was first formed as a voluntary organization in 1998 and later incorporated as a non-profit organization in 2002.

$5 \mathrm{BCA}$ is a statutory board under the Ministry of National Development of the Singapore Government. It was established on I April 1999 and the primary role is to develop and regulate Singapore's building and construction industry.
} 
Table I. General View of NSA Tools (GBIG; USGBC, 20I4; BRE, 20I2; DGNB, 20I2; JaGBC, 20I4; BCA, 20I3)

\begin{tabular}{|c|c|c|c|c|c|}
\hline Instrument & LEED ND & BREEAM COMM. & DGNB NSQ/NUD & CASBEE UD & GREEN MARK DISTRICTS \\
\hline Open Name & $\begin{array}{l}\text { Leadership in Energy } \\
\text { and Environment } \\
\text { Design -Neighborhood } \\
\text { Development }\end{array}$ & $\begin{array}{l}\text { Building Research } \\
\text { Establishment } \\
\text { Environ. } \\
\text { Assessment } \\
\text { Method (for) } \\
\text { Communities }\end{array}$ & $\begin{array}{l}\text { Deutsche } \\
\text { Gesellschaft für } \\
\text { Nachhaltiges Bauen } \\
\text { Neubau } \\
\text { Stadtquartiere New } \\
\text { Urban Development }\end{array}$ & $\begin{array}{l}\text { Comprehensive } \\
\text { Asses. System for } \\
\text { Built Environment } \\
\text { Efficiency Urban } \\
\text { Development }\end{array}$ & $\begin{array}{l}\text { Green Mark For } \\
\text { Districts }\end{array}$ \\
\hline $\begin{array}{l}\text { Releasel } \\
\text { Examined } \\
\text { Version } \\
\text { Date }\end{array}$ & $\begin{array}{l}2009 \\
2009\end{array}$ & $\begin{array}{l}2009 \\
2012\end{array}$ & $\begin{array}{l}2012 \\
2012\end{array}$ & $\begin{array}{l}2006 \\
2014\end{array}$ & $\begin{array}{l}2009 \\
2013\end{array}$ \\
\hline $\begin{array}{l}\text { Country of } \\
\text { Origin }\end{array}$ & USA & England & Germany & Japan & Singapore \\
\hline Developer & $\begin{array}{l}\text { U.S. Green Building } \\
\text { Council (USGBC) }\end{array}$ & $\begin{array}{l}\text { Building Research } \\
\text { Establishment } \\
\text { (BRE) }\end{array}$ & $\begin{array}{l}\text { German Sustainable } \\
\text { Building Council } \\
\text { (DGNB) }\end{array}$ & $\begin{array}{l}\text { Japan Sust. Build. } \\
\text { Consortium, } \\
\text { Japan Green } \\
\text { Buildings Council } \\
\text { (JaGBC) }\end{array}$ & $\begin{array}{l}\text { The Building and } \\
\text { Construction Authority } \\
\text { (BCA) }\end{array}$ \\
\hline $\begin{array}{l}\text { Imple- } \\
\text { mentation } \\
\text { Scales }\end{array}$ & $\begin{array}{l}\text { Used to assess small } \\
\text { or big areas including } \\
\text { various number of } \\
\text { buildings. When the } \\
\text { area is bigger than } \\
1295000 \mathrm{~m} 2 \text {, it is } \\
\text { recommended to } \\
\text { separate it into } \\
\text { smaller parts. }\end{array}$ & $\begin{array}{l}\text { No area size is } \\
\text { imposed and there } \\
\text { is no obligation, } \\
\text { but implementation } \\
\text { is advised in case } \\
\text { of some } \\
\text { circumstances. }\end{array}$ & $\begin{array}{l}\text { Area must be at least } \\
2 \text { hectares gross. } \\
\text { Housing areas } \\
\text { mustn't be less than } \\
10 \% \text { or higher than } \\
90 \% \text {. No objection } \\
\text { must be made by the } \\
\text { owners of the area } \\
\text { for the certification. }\end{array}$ & $\begin{array}{l}\text { Used to assess } \\
\text { both small and } \\
\text { big areas } \\
\text { accommodating } \\
\text { various numbers } \\
\text { of buildings. Areas } \\
\text { are divided into } \\
\text { two as the type } \\
\text { of city center } \\
\text { with high use and } \\
\text { low use. }\end{array}$ & $\begin{array}{l}\text { Examines the } \\
\text { development of the } \\
\text { districts with mixed use } \\
\text { and an area of at least } \\
20 \text { hectares. }\end{array}$ \\
\hline $\begin{array}{l}\text { Number } \\
\text { of Certif. } \\
\text { Projects }\end{array}$ & $\begin{array}{l}\text { 16I (registered and } \\
\text { certificated total) }\end{array}$ & 9 & 28 & 4 & 5 \\
\hline
\end{tabular}

NSA tools were examined. While there is no restriction about the area size in LEED, BREEAM and CASBEE NSA tools, it is seen that the smallest area size was determined for DGNB and Green Mark. The number of the projects which have been certificated so far or been at the stage of certification are given also on the table.

\section{Comparison of NSA Tools: Main Categories, Scoring and Grading}

Main categories and scoring system related to the NSA tools are shown in Table 2. One of the aspects of the SA tools, which are open to discussion, is the weighting of the categories. LEED-ND consists of 3 main categories and 2 additional categories which can gain extra points. 4l criteria that are subject to scoring exist under these categories except for II mandatory criteria (USBC, 20I4). BREEAM Com consist of
39 criteria under 5 main categories. Weight of each criterion is different from each other within the total (BRE, 20I2). DGNB new urban developments consist of the categories Ecologic Quality, Economic Quality, Sociocultural/Functional Quality and Technical Quality and less weighed Process Quality, weights of which are the same. In total, there are 45 criteria with I, 2 and 3 weights under those categories (DGNB, 20I2). In CASBEE-UD, environmental quality categories, which are determined as environment, society and economy, are divided into firstly medium and then small and smaller criteria; in total, 29 criteria (IBEEC, 20I4). The assessment instrument Green Mark assesses with the points given to 38 criteria, which have different points from I to 20, under 6 main categories. Differently from the other tools, calculation is made over 185 points in Green Mark (BCA, 20I3). When observed in general, it is seen that the numbers of the factors which will contribute to sustainability at 
Table 2. Main Categories, Scoring and Grading Systems in NSA Tools (USGBC, 20I4; BRE, 2012; DGNB, 20I2; JaGBC, 2014; BCA, 2013)

\begin{tabular}{|c|c|c|c|c|c|}
\hline Tool & LEED ND & BREEAM COMM. & DGNB NUD & CASBEE UD & GREEN MARK DISTRICTS \\
\hline $\begin{array}{l}\text { Main } \\
\text { Categories } \\
\text { (Point or } \\
\text { weights) }\end{array}$ & $\begin{array}{l}\text { Smart location and } \\
\text { connection- } 27 \text { points } \\
\text { Neighborhood model } \\
\text { and design- } 44 \text { points } \\
\text { Green infrastructure } \\
\text { and buildings- } 29 \text { points } \\
\text { Innovation and Design } \\
\text { Process- } 6 \text { points } \\
\text { Regional Priority } \\
\text { Credit } 4 \text { points }\end{array}$ & $\begin{array}{l}\text { Governance } 9.3 \% \\
\text { Social and } \\
\text { economic welfare } \\
41.7 \% \\
\text { Resource and } \\
\text { energy } 21.6 \% \\
\text { Land usage and } \\
\text { ecology } 12.6 \% \\
\text { Transportation and } \\
\text { movement } 13.8 \%\end{array}$ & $\begin{array}{l}\text { Ecologic Quality } \\
22.5 \% \\
\text { Economic Quality } \\
22.5 \% \\
\text { Sociocultural and } \\
\text { Functional Quality } \\
22.5 \% \\
\text { Technical Quality } \\
22.5 \% \\
\text { Process Quality } \\
10 \%\end{array}$ & $\begin{array}{l}\mathrm{Q}_{U D} \mathrm{I} \\
\text { Environment } \\
\mathrm{Q}_{U D} 2 \text { Society } \\
\mathrm{Q}_{U D} 3 \text { Economy } \\
\mathrm{L}_{\mathrm{UD}} \text { ITraffic-based } \\
\mathrm{CO} 2 \text { release } \\
\mathrm{L}_{U D} 2 \text { Building- } \\
\text { based } \mathrm{CO}_{2} \\
\text { release } \\
\mathrm{L}_{\mathrm{UD}} 3 \mathrm{CO}_{2} \\
\text { absorption of } \\
\text { green sector }\end{array}$ & $\begin{array}{l}\text { Energy Efficiency- } \\
32 \text { points } \\
\text { Water Management. - } \\
21 \text { points } \\
\text { Material and Waste } \\
\text { Manag. }-29 \text { points } \\
\text { Environmental Plan. } \\
42 \text { points } \\
\text { Green Buildings and } \\
\text { Green Transport. } \\
35 \text { points } \\
\text { Society and } \\
\text { Innovativeness } 26 \text { points }\end{array}$ \\
\hline $\begin{array}{l}\text { Scoring } \\
\text { System }\end{array}$ & $\begin{array}{l}\text { There are prerequisites } \\
\text { and criteria under each } \\
\text { category. Maximum } \\
100 \text { points can be } \\
\text { gained for } 41 \\
\text { criteria under the main } \\
\text { categories and extra } 10 \\
\text { points can be received } \\
\text { for } 3 \text { criteria under } \\
\text { the additional two } \\
\text { categories. }\end{array}$ & $\begin{array}{l}\text { In total, there are } \\
39 \text { titles in different } \\
\text { numbers in each } \\
\text { category. Total } \\
\text { weights of these } \\
\text { titles which include } \\
\text { different credits } \\
\text { vary between } \\
0.4 \% \text { and } 8.9 \% \text {. } \\
\text { Total point is } \\
\text { calculated by } \\
\text { summing the } \\
\text { credit points. }\end{array}$ & $\begin{array}{l}\text { In total, there are } 45 \\
\text { criteria with I, } 2 \text { and } \\
3 \text { weights assessed in } \\
\text { different ways. } \\
\text { Total point of all the } \\
\text { criteria under the } \\
\text { main categories } \\
\text { is } 100 .\end{array}$ & $\begin{array}{l}\text { All the main } \\
\text { categories from } \\
\mathrm{Q}_{U D} I \text { to } \mathrm{Q}_{U D} 3 \\
\text { consist of } 3 \\
\text { medium- level, } \\
\text { and medium-level } \\
\text { criteria consist of } \\
\text { small and smaller } \\
\text { sub-criteria. } \\
\text { There are no } \\
\text { sub-criteria for } \\
\text { the loads. }\end{array}$ & $\begin{array}{l}\text { In total, there are } 38 \\
\text { criteria in different } \\
\text { numbers under the main } \\
\text { categories. They have } \\
\text { different values changing } \\
\text { between I- to } 20 \text {. } \\
\text { Total scoring is } \\
\text { performed over } 185 \text {. }\end{array}$ \\
\hline $\begin{array}{l}\text { Grading } \\
\text { System }\end{array}$ & $\begin{array}{l}40+\text { points Certificated } \\
50+\text { points Silver } \\
60+\text { points Gold } \\
80+\text { points Platinum }\end{array}$ & $\begin{array}{l}\geq 25 \% \text { Passing } \\
\geq 40 \% \text { Good } \\
\geq 55 \% \text { Very good } \\
\geq 70 \% \text { Perfect } \\
\geq 85 \% \text { Prominent }\end{array}$ & $\begin{array}{l}>35 \% \text { Certificated } \\
>50 \% \text { Bronze } \\
\geq 65 \% \text { Silver } \\
\geq 80 \% \text { Gold }\end{array}$ & $\begin{array}{l}\text { C Weak BEE }<0.5 \\
\text { B- Quite Weak } \\
\text { BEE=0.5-I.0 } \\
\text { B+ Good } \\
\text { BEE=I.0-I.5 } \\
\text { A Very Good } \\
\text { BEE=I.5-3.0 } \\
\text { S Perfect BEE } \\
\geq 3.0\end{array}$ & $\begin{array}{l}>60 \text { Certificated } \\
>75 \text { Gold } \\
>90 \text { Gold plus } \\
>100 \text { Platinum } \\
\geq 85 \% \text { Prominent }\end{array}$ \\
\hline
\end{tabular}

the level of neighborhood are similar to each other in the 5 assessment systems, however, they sometimes gather with different expressions and under different titles And the real difference is seen in weighting; it is observed that similar criteria are scored differently in different assessment tools. The total points or weights calculated are graded over 100 for LEED-ND, BREEAM Com, DGNB NUD and over 185 for Green Mark for $D$ and according to the number of efficiency (Built Environment Efficiency (BEE) value) which is obtained with the division of the total environmental quality point into the total environmental load point in CASBEE-UD. The aforementioned grading systems are given in Table 2. While BREEAM takes the least passing point by $25 \%$, limit values and interval widths of the gradings are quite different from each other. On the other hand, the difference of the weights and scoring systems of the criteria in NSA tools prevents an objective comparison between gradings, in other words, makes it impossible to make a comment on which instrument obtaining a higher grading is easier at.

The number of the criteria and their percentage are categorized in Table 3 . In the same table scoring percentage is also given in another column, since the scores of the criteria are different from each other. It is seen from the table, that environment and land usage stands out in LEED and BREEAM, design and management in DGNB, social development in CASBEE, and three of environment and land usage, design and management and energy and resources in Green Mark, 
Table 3. Number and Percentages of Criteria (GBIG; USGBC, 20I4; BRE, 20I2; DGNB, 20I2; JaGBC, 20I4; BCA, 2013)

\begin{tabular}{|c|c|c|c|c|c|c|c|c|c|c|c|c|c|c|c|c|}
\hline \multirow[t]{2}{*}{ Category } & \multirow[t]{2}{*}{ What it contains } & \multicolumn{3}{|c|}{ LEED-ND* } & \multicolumn{3}{|c|}{ BREEAM } & \multicolumn{3}{|c|}{ CASBEE-UD } & \multicolumn{3}{|c|}{ DGNB } & \multicolumn{3}{|c|}{ GREEN MARK } \\
\hline & & Nu. & $\%$ & \% Scor. & Nu. & $\%$ & \% Scor. & Nu. & $\%$ & \% Scor. & Nu. & $\%$ & \% Scor. & Nu. & $\%$ & \% Scor. \\
\hline $\begin{array}{l}\text { Environment } \\
\text { and Land Usage }\end{array}$ & $\begin{array}{l}\text { Nature, biodiversity, } \\
\text { water management, } \\
\text { land usage }\end{array}$ & 17 & 35 & 25 & 12 & 30 & 24 & 6 & 21 & 21 & 7 & 16 & 14 & II & 29 & 35 \\
\hline $\begin{array}{l}\text { Economic } \\
\text { Development }\end{array}$ & $\begin{array}{l}\text { Employment, } \\
\text { new job, distant } \\
\text { work }\end{array}$ & I & 2 & 3 & 2 & 5 & 15 & 3 & 10 & 10 & 4 & 9 & 23 & - & 0 & 0 \\
\hline Transportation & $\begin{array}{l}\text { Public transport, } \\
\text { pedestrian and } \\
\text { bicycle road, } \\
\text { special cars, } \\
\text { parking area }\end{array}$ & 7 & 12 & 18 & 6 & 15 & 14 & 3 & 10 & 10 & 5 & 11 & 9 & I & 3 & 6 \\
\hline $\begin{array}{l}\text { Social } \\
\text { Development }\end{array}$ & $\begin{array}{l}\text { Life quality, } \\
\text { social } \\
\text { infrastructure, } \\
\text { urban context }\end{array}$ & 6 & 12 & 15 & 9 & 23 & 16 & 9 & 31 & 31 & 8 & 18 & 15 & 3 & 8 & 8 \\
\hline $\begin{array}{l}\text { Design and } \\
\text { Management }\end{array}$ & $\begin{array}{l}\text { Design principles, } \\
\text { heat islands, } \\
\text { policy and } \\
\text { governance }\end{array}$ & 9 & 18 & 26 & 4 & 10 & 9 & 4 & 14 & 14 & 13 & 29 & 19 & II & 29 & 26 \\
\hline $\begin{array}{l}\text { Resources and } \\
\text { Energy }\end{array}$ & $\begin{array}{l}\text { Waste management } \\
\text { material usage, } \\
\text { protection }\end{array}$ & 10 & 20 & 13 & 7 & 18 & 22 & 4 & 14 & 14 & 8 & 18 & 19 & 12 & 32 & 25 \\
\hline Total & & 49 & 100 & 100 & 40 & 100 & 100 & 29 & 100 & 100 & 45 & 100 & 100 & 38 & 100 & 100 \\
\hline
\end{tabular}

*There are 12 mandatory and 44 credited criteria. Criteria that are both mandatory and credited were accepted one.

in terms of the number and percentages of the criteria. While the transportation criteria are close to each other in the assessment tools except for Green Mark by percentage, the numbers of criteria related to the economic development are at almost insignificant level in the tools apart from CASBEE and DGNB. On the other hand the scoring percentages of the criteria give correct clues about at what level each category is considered significant in various assessment tools.

Environmental and land usage has the scoring weight by $20 \%$ or higher in all the tools other than DGNB (I4\%). While economic development has a weight above $20 \%$ in DGNB, it is too small as if never exists in LEED and has zero weight in Green Mark. Social development stands out in CASBEE, design and management in LEED and Green Mark with the highest percentages in terms of scoring. Resources and energy have a certain weight in all the systems, but this weight is higher in BREEAM and Green Mark. Whereas it is seen that transportation reaches a certain weight in all the tools, it stands out more in LEED and BREEAM.

\section{Conclusions, Assessment and Suggestions}

When the understanding "no non-assessable cases can be controlled" is taken as a reference, the need occurs for assessing the sustainable development, which is one of the most significant matters of today's world. Developed to fulfill this need, sustainable assessment systems turn the data into information to make better decisions and support the efforts of the decision-makers to create a more sustainable world environmentally, socially and economically in respect of buildings to cities.

In this study, updated versions of 5 third party NSA tools 
selected from different countries of the world were analyzed and implementation scales, the contained topics, main category and criteria, scoring and grading systems were examined in detail. Because all the assessment systems aim at providing sustainability in urban areas, it is possible to express that the approaches to sustainability are basically the same in the 5 systems examined. In this way, it was possible to categorize the criteria in all the systems under 6 main titles. However, it was discovered that systems revealed the matters in the scope of neighborhood sustainability in a different way. First of all, the expression of sustainability matters is different in each system. For example, matters related to energy were expressed under the main categories of green infrastructure and buildings in LEED, resource and energy in BREEAM, economic quality in DGNB, environmental quality in CASBEE and energy efficiency in Green Mark. The second issue is the difference in the number of criteria under various categories and their ratios to the total number of criteria and there is no agreement among systems in this matter. For example, the number of criteria related to social development was respectively determined as 6 (I2\%), 9 (23\%), 9 (3I\%), 8(I8\%) and $3(8 \%)$ in LEED, BREEAM, DGNB, CASBEE and Green Mark. The third maybe the most important issue is the fact that the weights of the criteria within the total sustainability and their scoring methods, details of which are not given in this study, are different. It is possible to say that the weights of the criteria and the scoring system are developed subjectively by the experts of the issue while forming the assessment systems. Because the criteria weights and the scoring system, which is formed depending on mostly the quantitative and sometimes qualitative indicators of these criteria, are substantially the measure of the success or failure in the certification of a project, subjectivity becomes more critical.

These results of the study reveal that the NSA tools, main goals of which are similar, are shaped in line with the local conditions. Population density, urban development and energy need that are three causes leading to the sustainability need differ from each other between countries and even sometimes within the country, therefore, we encounter this result as a natural situation, even an obligation. Haapio suggests that the characteristics of the NSA tools are determined on the basis of national standards, regulations, structural codes, cultural heritage, lifestyle and building culture (Haapio; 20I2), Sev stresses that the criteria and their weights must reflect the features of the district (Sev, 20II). When the intersystem differences approached within the scope of the study are reviewed, it appears that this situation can be followed on Green Mark in the most obvious way. Causes like small surface area of the country, high population and building density and almost no natural energy resources led to the appearance of the titles of environment and land usage, design and management and resources and energy. Substantial fulfillment of the needs in sense of transportation infrastructure, economy and social development in the country caused the weights of these titles approach almost zero. The dependence of the transportation on cars in the US and its position as a significant natural resource consumer led to giving the highest weight to transportation on LEED among all the systems. When it is considered that sensitivity to the protection of the environment is higher in Europe, it is possible to say that environment and land usage, resources and energy usage stand out naturally in BREEAM. It is interpreted that social development stands out in CASBEE and economic development in DGNB clearly compared to the other systems and it is considered that this results from the location-specific conditions. Consequently, the study reveals that the neighborhood assessment systems which are developed as important parts of the sustainable development goal at the global scale cannot be developed independently from the local conditions.

Increasing population, cities and urban infrastructures that continuously expand and threaten the natural areas and rapidly growing energy need has turned the goal of sustainable development into an obligation for the world. The increase in the cities and urban districts where the environmental quality decreases, energy systems are insufficient, industries and services decrease, sociodemographic structure is imbalanced, unemployment, poverty, inequality and stress are dominant and natural resources are consumed as if they are unlimited puts the cities into the focus point of the sustainable development goal. Making preparations for the future of the cities is very important for both increasing the life quality of the people who live in these cities and fulfillment of the responsibilities against humanity, environment and the world. Because it is not possible to give up on urbanization by reversing the history, cities mean living area, culture, information, philosophy, politics, history and they are the primary places where people can develop and realize themselves, these problems must be solved again in the cities.

Sustainability assessment instrument which are developed at a scale from buildings to cities and neighborhoods are candidate to become a significant part of this solution. Because the tools related to the assessment of the single buildings lack a holistic viewpoint, many dimensions of sustainability are ignored. Assessment systems for the whole city present limited success because the sustainability of their constituents isn't assessed. From this aspect, the NSA tools developed in recent years fill an important gap and they are expected to make greater progress in the future. Multidimensionality and complexity of the matter from many perspectives require more study and production of information. In this sense, it is assumed that this study, which examines the latest versions of five most-known third party neighborhood assessment systems, will make academic contribution. 


\section{REFERENCES}

Bond, A. J., Morrison-Saunders, A., (2011). Re-evaluating sustainability assessment: Aligning the vision and the practice, Environmental Impact Assessment Review 31 (1), pp. 1-7.

BCA- Building and Construction Authority (2013). Green Mark for Districts (Version 2.0), pp. 1-24.

BRE (Building Research Establishment) (2012). BREEAM Communities Technical Manual, SD202-0.1, pp. 1-181.

Choguill CL. (2008). Developing sustainable neighborhoods, Habitat Int, 32, pp. 41-48.

Cole, R.J. (2010). Environmental assessment: shifting scales. In: Ng E, editor. Designing high-density cities for social and environmental sustainability, London; Sterling, VA: Earthscan, pp. 273-282.

DGNB- Deutsche Gesellschaft für Nachhaltiges Bauen, (GeSBC, German Sustainable Building Council). (2012). Neubau Stadtquartiere: DGNB Handbuch für nachhaltiges Bauen, pp. 1-446.

Drakasis-Smith, D. (1997). Third world cities: sustainable urban development III, basic needs and human rights", Urban Studies, C.34, S. 5/6, pp. 796-825.

Geenhuisan, M., Nijkamp, P. (1994). Sürdürülebilir kenti nasıl planlamalı?, Nil, D. (Çev), Toplum ve Bilim Dergisi, Sayı: 64-65, pp. 129-140.

Haapio, A. (2012). Towards sustainable urban communities, Env. Impact Assessment Review 32 (1), pp. 165-169.

JaGBC- Japan Greeen Building Council (2014). CASBEE for Urban Development Technical Manual, pp. 1-49.

Kawakubo, S., Toshiharu I., Shuzo M. (2011). Nationwide assessment of city performance based on environmental efficiency, International Journal of Sustainable Building Techn. and Urban Development 2.4, pp. 293-301.

Mateus, R., Bragança, L. (2011). Sustainability assessment and rating of buildings: Developing the methodology SBTool PT-H., Building and Environment 46.10, pp. 1962-1971.

USGBC-U.S. Green Building Council, LEED 2009 for Neighborhood Development Rating System Created by the Congress for the New Urbanism, Updated July 2014, pp. 1-149.

Oktay, S.O., Özdede, S. (2012). Mevcut mahallelerin dönüşümünde yerele özgü çevresel değerleme metotlarının karşılaştırılması, Dünya Şehircilik Günü 36. Kolokyumu, Bildiri Kitabı, Ankara, pp. 217-231.

Orova, M., Reith, A. (2013). Comparison and evaluation of neighbourhood sustainability assessment systems. PLEA-29th Conference, Sustainable Architecture for a Renewable Future, Munich, Germany 10-12 September, pp. 1-6.

Panahi, M.Y. (2014). Neighborhood Sustainability Assessment in the New Developments of Tabriz, International Journal of Civil, Structural, Construction and Architectural Engineering Vol: 8, No:7, pp. 833-839.

Roosa, S. (2010). Sustainable Development Handbook--2nd edition, by the Fairmont Press. Printed in the USA, pp. 1-522.

Sev, A. (2011). A comparative analysis of building environmental assessment tools and suggestions for regional adaptations, Civil Engineering and Environmental Systems, Volume 28, Issue 3, pp. 231-245.

Sharif, A. (2013). Sustainability at the Neighborhood Level: Assessment Tools and the Pursuit of Sustainability, Graduate School of Environmental Studies Nagoya University, Unpublished PhD thesis, pp. 1-260.

Sharifi, A., Murayama, A. (2013). A critical review of seven selected neighborhood sustainability assessment tools, Environmental Impact Assessment Review 38, pp. 73-87.

Sharif, A., Murayama, A. (2014). Neighborhood sustainability assessment in action: Cross-evaluation of three assessment systems and cases from the US, the UK and Japan, Building and Environment 72, pp. 243-258.

Sharif, A., Murayama, A. (2015). Viability of using global standards for neighborhood sustainability assessment: Insights from a comparative case study, Journal of Environmental Planning and Management, Vol. 58, No. 1, pp. 1-23.

Soebarto, V. I., Williamson, T.J. (2001). Multi-criteria assessment of building performance: Theory and implementation, Building and Environment, 36.6, pp. 681-690.

Stone, D., Joseph, G. (2012). Neighborhoods go green: The story of LEEDND, Ontario Planning Journal, Vol. 27, no. 3, pp. 5-7.

Turner BL, Clark WC, Kates RW, Richards JF, Mathews JT, Meyer WB. (1990). The Earth as Transformed by Human Action: Global and regional changes in the biosphere over the past 300 years, Cambridge University Press with Clark, pp. 1-707.

\section{INTERNET REFERENCES}

The Green Building Information Gateway, http://www.gbig.org/, [Access date: 7 September 2015].

TURKECO İnşaat ve Enerji Ltd. Şti., http://www.turkeco.com/, [Access date: 20 November 2015]. 